\title{
Firm growth: A review of the empirical literature
}

\section{Rolando Vaz*1}

Universidade de Vigo, Facultade de Ciencias Económicas e Empresariais, Campus Universitario Lagoas-Marcosende, s/n, 36310 Vigo, Spain

Received: 20 October 2020 / Accepted: 4 February 2021

\begin{abstract}
The objective of this research is to review and unify the empirical literature that identifies the determining factors for firm growth. A list of 165 articles forms the backbone of the present review of the empirical literature on firm growth. Based on this review, we provide a synthesis of numerous determinant factors associated with firm growth. Specifically, we enumerate and detail the determining factors in three blocks: entrepreneur's idiosyncratic features, firm's internal factors, and factors external to the firm. The work provides a better understanding of the complex process of growth, shows the shortcomings in empirical research on the growth of the firm and presents directions for future research.
\end{abstract}

\section{Keywords}

Firm growth / External factors / Internal factors / Firm size.

\section{Crecemento empresarial: unha revisión da literatura empírica}

\section{Resumo}

O obxectivo desta investigación é revisar e unificar a literatura empírica que identifica os factores determinantes para o crecemento da empresa. Unha relación de 165 traballos constitúe a columna vertebral desta revisión da literatura empírica sobre o crecemento da empresa. A partir desta revisión, proporcionamos unha síntese de numerosos factores determinantes asociados co crecemento das empresas. En concreto, enumeramos e detallamos os factores determinantes dese crecemento en tres bloques: características idiosincráticas do empresario, factores internos e factores externos da empresa. 0 traballo proporciona unha mellor comprensión do complexo proceso do crecemento da empresa, mostra as deficiencias na investigación empírica sobre o dito crecemento e ofrece instrucións para futuras investigacións.

\section{Palabras clave}

Crecemento empresarial / Factores externos / Factores internos / Tamaño da empresa.

JEL Codes: D21, D23, D91, L21, L25, L26.

\section{Introduction}

Firms can create value through growth (Ortiz-de-Urbina-Criado, Guerras-Martín \& MontoroSánchez, 2014). Understanding the causes of firm growth becomes extremely important. At a microeconomic level, sustained firm growth creates new jobs; at a macroeconomic level, firm growth is a source of wealth creation and development of society (Ahlstrom, 2010; Dobbs \& Hamilton, 2007; Khan, 2011). Specifically, it is crucial to identify key factors that affect and trigger firm growth in support of policy measures that gear growth and increase employment. The vast empirical literature

\footnotetext{
${ }^{*}$ Corresponding author: rolando.vaz@sapo.pt

1 The author is grateful for the useful insights of two referees of this journal.
} 
seeking to identify these factors seems to confirm the relevance of this issue. This literature aims to find the true relationship between statistically significant factors and firm growth, and it has been frequently motivated by theoretical contributions. This is the case of the pioneering work of Gibrat (1931), which argues that growth is mostly random; the contributions of Edith Penrose (1959), who asserts that firms grow because of the existence of an idle internal structure or underutilized resources; or the work of Lucas (1978), which explains the growth of firms through the improvement of the idiosyncratic factors of the entrepreneur.

The main objective of the present study is to review the empirical literature that identifies the determinant factors for firm growth. The starting point for empirical literature is the premise that firm growth is not a random or a chance event, but is associated with specific factors and attributes. Thus, we group the determinant factors of firm growth into three blocks of analysis (see Table 1): (1) idiosyncratic factors, related to the entrepreneur's personal features (presented in section 2); (2) internal factors, related to the characteristics and resources specific to the firm (section 3); and (3) factors external to the firm, related to the environment surrounding it (section 4).

Table 1. Determining factors in firm growth

\begin{tabular}{lll}
\hline Entrepreneur & Internal & External \\
\hline 2.1. Motivation. & 3.1. Vision and mission. & 4.1. Political. \\
2.2. Education. & 3.2. Objective. & 4.2. Economic. \\
2.3. Experience. & 3.3. Strategic planning. & 4.3. Socio-cultural. \\
2.4. Age. & 3.4. Age. & 4.4. Technological. \\
2.5. Risk propensity. & 3.5. Size. & \\
2.6. Optimism and self-confidence. & 3.6. Sector. & \\
2.7. Gender and race. & 3.7. Location. & \\
2.8. Personal and professional networks. & 3.8. Legal form. & \\
2.9. Number of founders. & 3.9. Human resources. & \\
& 3.10. Financial resources. & \\
& 3.11. Organizational structure. & \\
\hline
\end{tabular}

Source: own elaboration.

This study builds on a comprehensive survey of the empirical literature on firm growth. Based on this research, we provide a synthesis of numerous determinant factors for firm growth. As for methodology: the search was conducted in Google Scholar and the Science Direct, using the search terms "determinants of the growth of the firm", "determinants of firm growth" and "firm growth and its determinants". A list of 165 articles cited including books, thesis, and conferences form the backbone of the present review. While analyzing these papers, citing paths both forwards and backwards were tracked, in order to achieve comprehensive coverage. In some cases, these works show the need for empirical analysis, whilst in others, heterogeneous contexts and samples with varying and specific results for each country, firm group, and markets are considered.

The present work considers different dimensions of firm growth. More specifically, this growth can be measured by studying the evolution of three variables representing the size of the firm: employment, sales or assets. The usual procedure for calculating growth rates is:

$$
\text { Growth }(t)=\log (\operatorname{Size}(t))-\log (\operatorname{Size}(t-1))
$$

Interestingly, the growth rate profile exhibits a robust and heavy-tailed distribution i.e. the Laplace distribution (Bottazzi \& Secchi, 2006). Consequently, growth is seen not as the outcome of a single 
lucky event allowing the firm to grow, but as the ability of determining factors to increase the growth of the firm. Based on this research, we provide a synthesis of numerous factors associated with firm growth.

This work presents two conclusions. Firstly, not all factors enumerated by empirical literature on the growth of the firm have a sound foundation, especially those variables related to factors external to the firm. Secondly, not all those variables identified by the empirical literature are the true factors that influence firm growth. In econometric analysis, the growth of firms is explained by statistically significant variables available from quantitative databases. However, some of these variables are not the "true" growth factors, but intermediate, proxy variables influenced by other underlying variables, the authentic factors affecting growth despite being unobservable in many cases. For instance, mature firms grow less than young firms do; yet this does not mean age is a factor that undermines the growth of the firm because other underlying factors (e.g., management capacity difficulties faced by an entrepreneur) could be reported as the true factor that slows down the development of the firm. Thus, in this work, we will be cautious when identifying factors as direct or indirect sources of firm growth.

\section{Idiosyncratic factors of the entrepreneur}

Based on the belief that a firm can be an extension of the entrepreneur (Chandler \& Hanks, 1994), many empirical works have aimed at identifying the key characteristics of entrepreneurs suggestive of influencing firm growth (Gilbert, McDougall \& Audretsch, 2006). Next, we enumerate them.

\subsection{Motivation}

Several empirical studies evidence the importance of the motivation of entrepreneurs in the growth of the firms (Barringer, Jones \& Neubaum, 2005; Baum \& Locke, 2004; Bibu \& Sala, 2014; Delmar \& Wiklund, 2008; Hampel-Milagrosa, Loewe \& Reeg, 2015; Kolvereid, 1992; Zhou \& Wit, 2009). The motivation for growth, or the intention to grow (Dutta \& Thornhill, 2008), may be associated with ambition, need for personal fulfillment, heightened notoriety and the possibility of gaining more power and money (Bibu \& Sala, 2014; Zhou \& Wit, 2009).

From the moment an entrepreneur decides to create the firm, this individual can be oriented towards growth, exploring opportunities (Delmar, 1996; Gundry \& Welsch, 2001; Olomi, 2001) or simply become an entrepreneur oriented towards independence and subsistence, being his/her own boss (Reeg, 2013). Yet even though entrepreneur motivation for growth is important, the entrepreneur's motivation and attitudes may change over time (Olomi, 2001; Reeg, 2013).

\subsection{Education}

A higher formal education level in entrepreneurs can help increase motivation and the ability to use a series of skills -management capacity, research and development, prospecting, communication, technology, among others that are useful for the firm management (Dobbs \& Hamilton 2007; Fadahunsi, 2012; Nichter \& Goldmark, 2009; Zhou \& Wit, 2009)- to increasing firms' growth opportunities (Rafiki, 2019). Even though higher levels of education are expected to increase entrepreneurs' ability to deal with problems and seize opportunities for firm growth and innovation (Reeg, 2013), empirical literature exposes mixed results concerning the education of the entrepreneur. Hassan \& Hart (2016) find no positive relationship between education and firm growth in Egypt. McPherson's (1996) study in South Africa also finds mixed results. However, Tarfasa, Ferede, Kebede \& Behailu (2016), in a study carried out in Ethiopia, affirm that education is statistically related to the growth of the micro-firms. Other authors verify that a high level of education increases entrepreneurs' 
ability to succeed when confronted with problems associated with growth (Barringer et al., 2005; Colombo \& Grilli, 2005; Cooper, Gimeno-Gascón \& Woo, 1994; Hampel-Milagrosa et al., 2015; Kolvereid, 1992; Reeg, 2013).

\subsection{Experience}

From the empirical evidence, we can conclude that the sector-related experience of the entrepreneur strongly correlates with the firm growth (Colombo \& Grilli, 2005; Cooper et al., 1994; Hampel-Milagrosa et al., 2015; McPherson, 1996; Siegel, Siegel \& Macmillan, 1993; Watson, Stewart \& BarNir, 2003) and is a precondition for success (Barringer et al., 2005; Demir, Wennberg \& McKelvie, 2017; Duchesneau \& Gartner, 1990; Fadahunsi, 2012; Zhou \& Wit, 2009). However, the experience acquired in other firms and previous experience in the sector is more important than experience per se because they provide the entrepreneur with a better decision capacity (Barringer et al., 2005; Gilbert et al., 2006), as well as a personal network of potential clients or suppliers, that facilitates better access to the market (Wiklund, 1998). Management experience (Demir et al., 2017), fundamentally in organizational activities (Rafiki, 2019), has a significant impact on the growth of firms due to a higher level of specialization (Dobbs \& Hamilton, 2007) and can help reduce organization costs.

\subsection{Age}

Although the entrepreneur's age is oftentimes used as a factor affecting growth ambition (Zhou \& Wit, 2009), the empirical literature presents mixed results. Some studies find an inverse relationship between the age of the entrepreneur and the growth of the firm: firms managed by younger entrepreneurs are more likely to grow (Hassan \& Hart, 2016; Kangasharju, 2000; Tarfasa et al., 2016) and younger entrepreneurs expect their firms to grow more than the firms managed by older entrepreneurs (Bager \& Schøtt, 2004; Delmar, 1996). Other authors evidence that the age of the entrepreneur is unrelated to the growth of the firm (Cassar, 2006). Belenzon, Shamshur \& Zarutskie (2019) found that as an entrepreneur ages the firm experiences lower sales growth. Finally, some studies verify that older entrepreneurs present, on average, better conditions and resources to make their business grow (Fadahunsi, 2012; Reeg, 2013). Even though young entrepreneurs are more willing to take risks, they will always have fewer networks and less time to accumulate necessary resources. Therefore, in the case of liquidity constraints, young entrepreneurs will find it more difficult to borrow enough money to sustain business growth and development (given their fewer guarantees). From another perspective, the preferences of the entrepreneur can change over time -risk aversion is associated with age (Pålsson, 1996), and it increases consistently with age (Yao, Sharpe \& Wang, 2011). Older individuals will probably have less need to obtain additional income or, even more so, may likely have already attained initial aspirations defined when creating the firm (Davidsson, 1991). Finally, the variable age can be an intermediate variable (indirect factor), affected by other underlying variables that effectively influence the growth of the firm, such as those that are idiosyncratic to the entrepreneur (risk aversion, experience, and motivation) and/or external to the firm (financial constraints).

\subsection{Risk propensity}

The empirical literature shows that the ambition and the desire to take risks are characteristics of those entrepreneurs that present more tendency for growth (Hampel-Milagrosa et al., 2015). Entrepreneurs with no risk aversion expect their firms to grow more than those of risk-averse entrepreneurs (Bager \& Schøtt, 2004). Uncertainty and risk are important factors in the act of undertaking and making a firm grow (Zhou \& Wit, 2009). Risk propensity is related to other internal 
factors of the firm e.g. size and age (Wennberg, Delmar \& McKelvie, 2016), as well as idiosyncratic factors, such as age and motivation. Different entrepreneurs have different attitudes towards risk and uncertainty, and risk aversion changes with age (Pålsson, 1996; Yao et al., 2011). Ambition (motivation) and risk are factors that cannot be disaggregated from the process of firm growth: participating in entrepreneurial activities means taking on personal and financial risk (Davidsson, 1989; Drucker, 1999; Knight, 1921; Schumpeter, 1934) especially at the beginning of an undertaking (Sexton \& Bowman, 1985).

\subsection{Optimism and self-confidence}

The empirical literature concludes that optimistic entrepreneurs expect their firms to grow more than those of less optimistic entrepreneurs (Bager \& Schøtt, 2004; Storey, 2011). Optimism and selfconfidence reflect different aspects of the entrepreneur's personality and influence business behavior (Davidsson, 1991). Successful entrepreneurs can influence their employees, customers, suppliers, and funders if they present a high level of optimism and self-confidence (Casson, 2005). By influencing their environment, entrepreneurs can also improve firm performance (Baum \& Locke, 2004; Davidsson, 1989). Therefore, an entrepreneur with an elevated degree of optimism and selfconfidence may induce a greater level of growth in the firm.

\subsection{Gender and race}

The empirical literature concludes that, per se, race (or ethnicity) and gender are not a significant factor for explaining the firm growth given that they show a high degree of ambiguity (Coad \& Tamvada, 2012; Cooper et al., 1994; Hampel-Milagrosa et al., 2015; Karadeniz \& Özçam, 2010; McPherson, 1996; Zhou \& Wit, 2009). Regarding race, Edelman, Brush, Manolova \& Greene (2010) point out significant differences in the motivations and intentions for firm growth among black and white entrepreneurs. Regarding gender, some studies show that men present more ambition to make their firms grow than women (Bager \& Schøtt, 2004). Other authors evidence that firms managed by men grow faster (Arroyo, Fuentes \& Jiménez, 2016; Coad \& Tamvada, 2012; Liedholm, 2002) and tend to be larger (Cliff, 1998). However, Davidsson, Achtenhagen \& Naldi (2010) mention that lower growth is likely an effect of the sector rather than a true gender effect. Finally, the variables gender and race are probably an intermediate variable (indirect factor) affected by other underlying variables that effectively influence growth, such as the motivation of the entrepreneur and his contact network. Moreover further studies are required to identify unobserved factors that contribute to the lower performance among entrepreneurs of ethnic minorities and women (Cooper et al., 1994).

\subsection{Personal and professional networks}

The empirical literature concludes that the network (social and professional) and contacts previously developed by the entrepreneur in similar industries diminish the risk of error, and they play an important role in the process of creation and growth of firms (Hampel-Milagrosa et al., 2015; Ostgaard \& Birley, 1996; Reeg, 2013; Zhao \& Aram, 1995). The network permits entrepreneurs to use external resources to grow beyond the limits established by the internal resources that currently control them (Jarillo, 1989), compensating for the shortage of tangible and intangible resources (Zhao \& Aram, 1995). The use of these additional resources is fundamental in explaining above-average growth. For example, the resource base in small firms is limited, and it becomes fundamental for the entrepreneurs to obtain resources through their personal networks (Ostgaard \& Birley, 1996; Stam, Arzlanian \& Elfring, 2014) or the development of relationships with external organizations (Street \& Cameron 2007), e.g. universities (Cassia, Colombelli \& Paleari, 2009). Furthermore, external social 
capital (for example, support from associations or consultants) has a positive effect on firm growth. Networks are (additionally) a socially constructed "strategic alliance" to help in operations, but they also help institute change and growth in new markets susceptible to be reinforced by the knowledge and reputation of network partners (Anderson, Dodd \& Jack, 2010). Entrepreneurs with strong sociability and the capacity to maintain and develop networks with suppliers, consultants and clients increase the probability of success and, consequently, the growth of the firm (Zhou \& Wit, 2009). Finally, there exists evidence that firms that seek growth maintain and improve a close relationship with their customer network by actively developing new products and services for existing or new customers, obtaining higher levels of growth (Delmar, 1996; Smallbone, Leig \& North, 1995). The customer network can be related to other internal factors, namely the size of the firm and motivation (Rafiki, 2019).

\subsection{Number of founders}

The number of founders can be an advantage for firm growth because larger teams possess more talent and resources than a single entrepreneur (Barringer et al., 2005; Gilbert et al., 2006). Empirical literature supports the notion that diversity, quality (work experience, education, and other skills) and motivation of the management team (founding) potentiate firm growth (Colombo \& Grilli, 2005; Davidsson et al., 2010). Different constituent members of a team compound the deficits of competence of one another (Davidsson, Achtenhgagen \& Naldi, 2005), i.e., synergistic gains may arise from the heterogeneity of the founding team's capabilities (Colombo \& Grilli, 2005). This factor is derived from the natural consequence of two determinants, experience and education (Dobbs \& Hamilton, 2007). Thus, a greater number of founders (or managers) provides the knowledge base and know-how to expand and thereby improves the perspectives of firm growth (Cooper et al., 1994).

\section{Internal factors of the firm}

Empirical literature explores a second group of factors, internal factors, to explain firm growth. We can distinguish between two groups of internal factors: those characterizing the essence of the firm and those which are related to the specific resources.

In this section, we focus on the empirical literature that considers firm growth is not a random or a chance event, but is associated with specific firm attributes (Barringer et al., 2005). Next, we enumerate these factors.

\subsection{The vision and mission}

The empirical evidence recognizes that growth-oriented vision and mission are significant internal factors that increase the growth rate and survival of firms (Barringer et al., 2005; Hove \& Tarisai, 2013). When vision and mission are focused on growth and this is known and understood by all employees and stakeholders, it causes an indirect effect on growth through specific objectives, as well as a direct effect through increased chances of growth (Baum \& Locke, 2004; Baum, Locke \& Kirkpatrick, 1998; Mazzarol, Reboud \& Soutar, 2009).

\subsection{The objective(s) of the firm}

Firms are created and oriented with one objective(s) (Schein, 2004), which should be aligned with the firm's vision and mission. The empirical literature recognizes that the firm's objective, a commitment and motivation to grow, is a characteristic of fast-growing firms because they present a stronger commitment to growth (Barringer et al., 2005). Therefore, one of the main approaches to firm 
growth pass by answers this question: What are the interests of the entrepreneur and the interests of the firm? (Nelson \& Winter, 1982). Given that the entrepreneur is the actor who decides to create a firm -create a kingdom (Schumpeter, 1934)-, the decision to make a firm grow is also the entrepreneur's choice (Kolvereid, 1992; Wright \& Stigliani, 2012). Growth is not always an objective for the entrepreneur (who can have other ambitions), so a growth-oriented firm requires their objectives be aligned with the objectives of the entrepreneur (Dobbs \& Hamilton, 2007; Smallbone et al., 1995).

\subsection{Strategic planning}

Strategic planning is a means of preparation for the future of the firm (Klag \& Langley, 2014) and has been widely used as an instrument to optimize firm performance. Planning helps a firm organize for growth. Firms that plan in a conscientious and realistic, thorough manner, have better chances of reaching their growth objectives (Barringer et al., 2005). The empirical evidence recognizes that strategic planning -in particular, the existence of a business plan (Hove \& Tarisai, 2013; Shuman, Shaw \& Sussman, 1985)- can help improve the performance and organization of the firm for its survival and growth (Arend, Zhao, Song \& Im, 2015; Greiner, 1972; Mazzarol et al., 2009; Scott \& Bruce, 1987). Successful firms spend more time planning than do unsuccessful firms (Duchesneau \& Gartner, 1990). According to Barringer \& Greening (1998), the planning of a firm's geographical expansion is also important for growth. However, Barringer et al. (2005) find no significant differences, relative to planning, between fast-growing and slow-growing firms.

\subsection{Age}

The empirical literature exposes that age presents an inverse relation to firm growth (Burger, Damijan, Kostevc \& Rojec, 2017; Evans, 1987; Liedholm, 2002; McPherson, 1996): the small and young firms (conditional on survival, Haltiwanger, Jarmin \& Miranda, 2013), as opposed to large and mature firms, present higher growth rates (Audretsch, 2012; Coad, Dunfeldt \& Halvarsson, 2018; Coad, Segarra \& Teruel, 2016; Davidsson, Kirchhoff, Hatemi-J \& Gustavsson, 2002; Hampel-Milagrosa et al., 2015; Harabi, 2007; Morone \& Testa, 2008; Variyam \& Kraybill, 1992). This happens because the performance of mature firms deteriorates with age. These types of firms may have developed inadequate routines for market requirements (Glancey, 1998), while the flexibility and less rigid routines of small and young firms provide them with advantageous growth opportunities (Davidsson et al., 2010; Sapienza, Autio, George \& Zahra, 2006). Coad, Segarra \& Teruel (2013), in an analysis on a panel of Spanish industrial firms, evidence that firms improve their performance with age: the mature firms have increasing levels of productivity, higher profits, larger size, lower debt ratios, and higher capital ratios. This contrasts with previous empirical studies. However, some authors argue that young firms are not always more likely to grow, in comparison with mature firms (Davidsson et al., 2010; Fadahunsi, 2012). On the one hand, young firms may not be as efficient and face financing constraints at the beginning of their activity (Reeg, 2013). On the other hand, mature firms may use their reputation to offer complementary products (cross-selling) or higher value products (up-selling). Finally, the variable age may be an intermediate variable (indirect factor), affected by other underlying variables that indeed influence firm growth, like the entrepreneur's idiosyncratic factors (risk aversion, networks, and motivation), internal factors of the firm (size), or external factors (financial restrictions).

\subsection{Size}

Since its presentation, Gibrat's Law (1931) has become a reference for empirical investigation on firm growth (Becchetti \& Trovato, 2002; Distante, Petrella \& Santoro, 2018; Parker, 2009; Sutton, 
1997). However, most empirical analyses reject it (Almus \& Nerlinger, 1999; Brenner \& Schimke, 2015; Hall, 1987; Mateev \& Anastasov, 2010): size presents an inverse relationship to the firm's growth. Small firms are expected to grow more (Liedholm, 2002) and more rapidly (Audretsch, 2012; Coad \& Tamvada, 2012) than large firms (Oliveira \& Fortunato, 2003; Simbaña-Taipe, Rodríguez-Gulías \& Rodeiro-Pazos, 2018). This is because small firms typically have the need to achieve a minimum efficiency scale (or optimum size) that allows them to achieve profitability and survival within the sector (Burger et al., 2017; Davidsson et al., 2002). As firms get older or become larger, their growth rate declines due to the scale effect (Tarfasa et al., 2016). Therefore, larger firms have possibly already found their optimal size, or they are really close to it (Singh \& Whittington, 1975). On the other hand, Canarella \& Miller (2018) differ from most findings in the literature, the small firms in the information and communication technology industry do not grow faster than large firms. Finally, we can argue that firm size and age are related.

\subsection{Sector}

The empirical literature points out that emerging or growing sectors, with greater business opportunities, facilitate firm growth more than mature, fragmented or declining sectors (Bauer, Dao, Matzler \& Tarba, 2017; Sirmon, Hitt \& Ireland, 2007; Smallbone et al., 1995). For example, emerging sectors with small firms developing profitable niche markets (Wiklund, Patzelt \& Shepherd, 2009) generate faster growth -interstices in an economy (Penrose, 1959). In the literature, sectors are defined according to the products and/or services produced (Davidsson et al., 2002). It is important to note that the empirical research of the growth of firms has been carried out in the manufacturing industry, -focusing on the analysis of high-tech firms- construction, and the services sector. The empirical literature shows that the firms present more resistance to growth in the service sector as compared to the manufacturing and construction sectors (Cooper et al., 1994; Kolvereid, 1992; McPherson, 1996). As opposed to previous studies, Mateev \& Anastasov (2010) argue that the sector (production or services) where the firms operate has no significant impact on firm growth. Notwithstanding these opposing results, the sector is a factor to be considered when analyzing firm growth (Liedholm, 2002). The variable sector is possibly an intermediate variable (indirect factor), for example, the sector where a firm operates cannot determine whether the firm grows because some firms intend to be small from the start. Thus, this variable is affected by other underlying variables that indeed influence firm growth, i.e. the entrepreneur's idiosyncratic factors (networks and motivation), internal factors (geographical location) and external factors (technological environment).

\subsection{Location}

Empirical literature recognizes that the concentration of economic activity in a geographic area has a significant impact on firm growth (Harabi, 2007; Hoogstra \& van Dijk, 2004; McPherson, 1996; Storey, 1994). The firm's location is interlinked with other factors: internal, the sector where the firm operates; and external, the economic environment, determining the number of competitors. Some geographical areas are more favorable than others for the firm's growth depending on the number of competitors and the sector (Davidsson et al., 2002; Storey, 1994). Many competitors can represent fewer chances for the firm to survive and grow (Folta, Cooper \& Baik, 2006). Due to the intense competition for resources, firms that are more attractive to the resources are more likely to grow (Lee, 2018). However, firms located in areas with a high concentration of business acquire a location advantage (location externalities), as is the case of firms located within an industrial district, or cluster, like Silicon Valley (Pyke, Becattini \& Sengenberger, 1990; Tarfasa et al., 2016). Clusters often create positive externalities. These positive externalities potentiate growth, especially small and 
medium-sized firms (Altenburg \& Meyer-Stamer, 1999), by enabling them to access specialized resources (Barringer et al., 2005; Cuervo-Cazurra, de Holan \& Sanz, 2014) that are either unavailable to other firms located outside that geographical area or available to them at a higher cost (Pe'er, Vertinsky \& Keil, 2016). However, given the dynamics of the environment where the firm is inserted, the ideal location can change over time. Yet this does not imply that firms move frequently, because the process of the delocalization itself can be rather costly (Hoogstra \& van Dijk, 2004). Finally, the variable location is possibly an intermediate variable (indirect factor), affected by other underlying variables that, indeed, influence firm growth, such as external factors (political, economic, sociocultural and technological environment).

\subsection{Legal form}

Firms can take on several different legal forms, but paramount among them is the limited responsibility legal form (Davidsson et al., 2002). The empirical literature indicates that the legal form in which a firm is constituted influences its growth rate. In particular being a limited responsibility firm correlates positively with growth prospects (Fadahunsi, 2012; Harabi, 2007; Storey, 1994). The limited responsibility companies free entrepreneurs of some types of responsibility allowing them to take greater risks. Thus, these firms typically grow faster than unlimited responsibility firms (Almus \& Nerlinger 1999; Harhoff, Stahl \& Woywode, 1998). However, another important issue arises concerning changes in business governance (Davidsson et al., 2002). Many firms are wholly or partially owned by other firms, and many have joint-stock ownership. Some of these relationships extend to acquisitions, mergers, franchising and joint ventures among others (changing resource availability that promotes or inhibits growth). This meets the legal needs firms present as they grow. Finally, the legal form is not a direct cause of growth because the firm objectives (internal factors) can change over time (McKelvie \& Wiklund, 2010), and entrepreneurs eventually may opt to change the legal form of the firm according to their attitudes toward growth (Davidsson et al., 2002).

The growth of a firm can also be influenced by the available specific firm resources and the way these resources are organized (Zhou \& Wit, 2009). The two most important resources for firm growth are human and financial (Gilbert et al., 2006). Next, we address these factors and organizational structures.

\subsection{Human resources}

The economic growth literature of the 80s and 90s (Mankiw, 1995; Romer, 1986, 1990) identifies human capital as one of the key factors for the growth of economies and, therefore, for the growth of firms (Barbero, Casillas \& Feldman, 2011; Demir et al., 2017; Lee \& Temesgen, 2005). The empirical literature recognizes that human resources (with more knowledge, skill and experience influence the process of endogenous growth) are determinants for firm success and growth (Florin, Lubatkin \& Schulze, 2003; Rauch, Frese \& Utsch, 2005). Moreover, the lack of this resource may limit growth (Hampel-Milagrosa et al., 2015; Kumar, 2016; Psenicny, 2009). On the one hand, existent human capital in the firm is an intangible asset capable of generating specific knowledge that may constitute a sustainable competitive advantage (Bamberger, Biron \& Meshoulam, 2014; Barney, 1991). In addition, human capital is a source of wealth for the development of innovative activities, which can increase firm productivity and competitiveness (Gilbert et al., 2006; Todd \& Taylor, 1993). According to Penrose (1959), the firm grows in the presence of idle or underutilized resources within its structure, along with managers with experience and management capacity to control new additional resources. A firm needs to incorporate new resources as it grows, progresses, and scales to a new level. Although firms can grow by producing "more of the same," a time will come when they have to incorporate new employees and create new production layouts to produce more (Coad, 2007). Specialized functions 
emerge as the firm grows and, once the number of employees and departments in the firm increases, some individuals must assume supervisory or management functions (Picken, 2017).

\subsection{Financial resources}

The empirical literature indicates that the lack of financial resources and the difficulty in gaining access to them can inhibit firm growth (Arellano, Bai \& Zhang, 2012; Binks \& Ennew, 1996; HampelMilagrosa et al., 2015; Psenicny, 2009). Financial capital is indispensable for the survival and growth of firms (Lee, Wang \& Ho, 2019). We must be aware that there are two sources of financial resources to assess the contributions of empirical literature: the internal resources, financial capital from the injections of capital provided by the entrepreneur and the profits of the firm; and external resources, originating from financial institutions and the capital market. The decision concerning the way to finance is linked to the motivation of the entrepreneur -his desire to maintain, or not, total control of the business in exchange for external capital- and the growth orientation of the firm (Dobbs \& Hamilton, 2007). Firms that self-finance through their own profits minimize growth costs because they do not need to pay interest or dividends (Kunt-Demirgüç \& Maksimovic, 1998; Mateev \& Anastasov, 2010; Oliveira \& Fortunato, 2006; Pissarides, 1999; Rahaman. 2011). Otherwise, they are more dependent on external financing to potentiate their growth (Silva \& Carreira, 2011). Therefore, financial capital (internal or external) is indispensable for growth because it can easily be converted into other types of resources that may increase productivity (Carpenter \& Petersen, 2002; Coad et al., 2013; Cooper et al., 1994; Guariglia, Liu \& Song, 2011; Hermelo \& Vassolo, 2007; Segarra \& Teruel, 2009; Tarfasa et al., 2016; Zhou \& Wit, 2009). Finally, we can say that internal financial resources are related to the idiosyncratic characteristics of the entrepreneur (motivation, number of founders, networks, and personal and family resources) and the internal factors of the firm (vision). The external resources are correlated with the idiosyncratic characteristics of the entrepreneur (age, equity), the internal factors of the firm (financial indicators and equity), and the external factors (political and economic) that portray the characteristics of the financial system surrounding the firm and determining external financing options (Cagetti \& Nardi, 2006).

\subsection{Organizational structure}

The empirical literature recognizes that the organizational structure is important (Meijaard, Brand \& Mosselman, 2005), since the design and hierarchize the organization of the firm are basic decisions that an entrepreneur or manager of a firm needs to make. Usually, a firm starts with a single individual, the entrepreneur; he assumes all responsibilities (sales, purchasing, production, and finance, among others). From the moment the firm starts to grow, it will necessarily have to hire employees and subsequently develop an organizational structure to accommodate and integrate new resources (Todd \& Taylor, 1993). As the firm grows, management responsibilities expand beyond the capacity of the entrepreneur (Mount, Zinger \& Forsyth, 1993). This forces the entrepreneur to delegate responsibilities (Gilbert et al., 2006; Smallbone et al., 1995) and decision-making becomes more decentralized. The firm ends up creating a multi-unit administration through administrative hierarchies of authority (Chandler, 1980; Mintzberg, 1979; Mount et al., 1993). The organizational structure is an element associated with the definition of rules, policies, and procedures on the functioning of the firm. As the firm grows it becomes more complex, and this leads to the development of new processes and routines (Pe'er et al., 2016). The organizational structure facilitates noncontractual exchanges within the firm (Wintrobe \& Breton, 1986). Thus, firms must create flexible structures that allow them to respond to changes throughout their growth path. In addition, the organizational structure can be affected by idiosyncratic factors of the entrepreneur (such as experience and networks), by internal factors (size, sector, and strategic planning) and external factors (economic, socio-cultural and technological). 


\section{Factor external to the firm}

The external environment of the firm is comprised of all the factors that provide opportunities or threats to the firm and that are beyond the entrepreneur's control (Gopinath, 2012). These factors can be disaggregated from the PEST analysis (political, economic, socio-cultural and technological) (Fadahunsi, 2012; Gupta, Guha \& Krishnaswami, 2013). In this section, we found no empirical evidence for external factors other than economic factors. However, political, socio-cultural and technological factors are also relevant because the dynamism of the sector, country, city or region, may vary and influence firm development and growth.

\subsection{Political factors}

The political environment -e.g., political stability, labor regulations, fiscal and trade policy constraints- refers to factors related to the environment where the government through the implementation of its public policies can affect the modus operandi of the firm. Political stability encourages firms to invest in new projects: strong political institutions represent low political risk and the absence of uncertainty in future government policies, which can stimulate investment and create incentives for firm growth (Boubakri, El Ghoul \& Saffar, 2015; Reeg, 2013). On the contrary, political institutions influence firm growth, directly through the restriction, limitation or even the exclusion of a firm's entry into an activity sector through licenses or restrictions on access to raw materials (Djankov, La Porta, López-de-Silanes \& Shleifer, 2002) or they may indirectly do so by establishing entry barriers, for example, by requiring control standards on air and water pollution or establishing safety regulations (Porter, 1985). Finally, the appropriate role of the state (government) is to encourage firms to achieve higher levels of performance and competitiveness (Porter, 1999).

\subsection{Economic factors}

The economic environment -unemployment, interest rates, inflation rate- is another aspect that can cause several reactions in the behavior and growth of firms (Bibu \& Sala, 2014). The external economic factors can affect the firm's supply and demand, e.g., due to high interest-rate loans to potential clients. An example of one economic factor that provides positive effects in firm growth is the growth of the sector and the dynamism of the region (Davidsson et al., 2010). A negative example is the difficulty to raise capital in credit markets for financing new resources (investments) or new developments (Binks \& Ennew, 1996; Fazzari, Hubbard, Petersen, Blinder \& Poterba, 1988; Pissarides, 1999). The availability and cost of capital are a factor that affects investment decisions (Cooley \& Quadrini, 2001). Restricted access to finance is, therefore, a potentially significant constraint to firm growth (Ullah, 2019). As evidenced in the empirical literature: restrictions in loans generate less concentration of wealth and reduce the average size of the firm (Cagetti \& Nardi, 2006; Rajan \& Zingales, 1998). The essential argument is that services provided by the financial sector are an essential catalyst of firm growth (Oliveira \& Fortunato, 2006), as aforementioned in the internal factors of the firm when we talk about financial resources.

\subsection{Socio-cultural factors}

Among others, these are the demographics, ethnicity, tastes, preferences, lifestyles and social values that affect population demand patterns. Kangasharju (2000) mentions that the demand for the firm's products is the main external determinant that affects growth. In this sense, periods of high demand can trigger the growth of the sector increasing the firm's chances of survival and growth (O'Gorman, 2001). However, demand patterns can play an important role in the definition and direction of technological change (Klepper, 1996). 


\subsection{Technological factors}

Technological factors -innovation, R\&D, patent registration, new equipment, among others- can influence the growth of the firm (Whetten, 1987). Firms belonging to the same sector can differ, among other things, in terms of the technology they use. One of the key reasons that firms display wide productivity levels and growth differences is the technology adopted in the production process (Du \& Temouri, 2015). While firms disappear as technologies become obsolete, firms successfully implementing innovation will remain in the sector and increase their production/productivity (Jovanovic \& MacDonald, 1994). The firms where knowledge is an important factor may benefit from external sources of knowledge (Duschl, Schimke, Brenner \& Luxen, 2011). Although technological knowledge is available in all regions, only regions with a qualified workforce reap the benefits (Hoogstra \& van Dijk, 2004).

\section{Conclusions}

This paper reviews the empirical literature that addresses the determinant factors of firm growth. It synthesizes the literature and groups the factors into three blocks: idiosyncratic features of the entrepreneur, internal factors and factors external to the firm. This structure permits a better understanding of the complex process of firm growth.

Our review allows us to identify the main factors affecting firm growth. Concerning the idiosyncratic factors of the entrepreneur, the main factors considered to be an advantage to firm growth by empirical literature are motivation, education, experience, risk propensity, optimism and self-confidence, personal and professional networks and the number of founders. Less clear is the effect of age, gender, and race. The reason is they are indirect factors, affected by other underlying variables that effectively influence the growth of the firm. Concerning internal factors -specific characteristics and resources of the firm- the empirical literature identifies the following main factors as positively related: vision and mission, the objective(s) of the firm, strategic planning, size, localization, human resources, financial resources, and organizational structure. The age of the firm, the sector, and the legal form are less clear in terms of their association with firm growth. The reason is they are indirect factors, affected by other underlying variables. Finally, concerning the external factors that directly influence firm growth, the empirical literature has focused on the economic factors, and specifically the restricted access to finance is a significant constraint for firm growth. No empirical evidence was reported for political, socio-cultural and technological factors (although we can assert that successful firms in implementing innovation activities will survive in the sector, increase their production/productivity, and, thus, grow).

Our paper points out three future lines of research. In the first place, greater effort is needed to delimit what constitutes a variable of direct influence on firm growth regarding variables of indirect influence. As observed by Storey (2011),

When faced with a requirement to improve explanatory power, researchers use combinations or clusters of independent variables that, in themselves, have no obvious meaning. While this improves the explanatory power of the models, it does so by using the unexplainable to explain the inexplicable (Storey, 2011, p. 317).

The second potential line of research is to encourage the continued development of empirical research and exploring the possible presence of other variables related to firm growth, as is the case of the integration in value chains, strategies for growth (innovation, internationalization, diversification) $R \& D$, patents, agency costs, investor protection, capital structure, foreign versus domestic ownership, dynamic capacity and absorptive capacity or others. The exploration of these two lines of research will 
allow the development of new public policies aimed at growth. A third line of research is to empirically disentangle the relevance of factors that increase both expected growth and exit, which could possibly lead to concerns about selection bias. For instance, education increases expected growth, but also decreases survival chances (Gimeno, Folta, Cooper \& Woo, 1997), because highly-educated entrepreneurs have outside options and might be fast to leave if their business does not come up to expectations. Innovative firms have higher chances of growth (if successful) or exit (if unsuccessful).

\section{References}

Ahlstrom, D. (2010). Innovation and growth: How business contributes to society. Academy of Management Perspectives, 24(3), 11-24. DOI: http://dx.doi.org/10.2139/ssrn.2643390

Almus, M., \& Nerlinger, E. A. (1999). Growth of new technology-based firms: which factors matter? Small Business Economics, 13(2), 141-154.

Retrieved from: https://citeseerx.ist.psu.edu/viewdoc/download?doi=10.1.1.473.7764\&rep=rep1\&type=pdf

Altenburg, T., \& Meyer-Stamer, J. (1999). How to promote clusters: Policy experiences from Latin America. World Development, 27(9), 1693-1713. DOI: https://doi.org/10.1016/S0305-750X(99)00081-9

Anderson, A. R., Dodd, S. D., \& Jack, S. (2010). Network practices and entrepreneurial growth. Scandinavian Journal of Management, 26(2), 121-133. DOI: https://doi.org/10.1016/i.scaman.2010.01.005

Arellano, C., Bai, Y., \& Zhang, J. (2012). Firm dynamics and financial development. Journal of Monetary Economics, 59(6), 533-549. DOI: https://doi.org/10.1016/j.jmoneco.2012.06.006

Arend, R. J., Zhao, Y. L., Song, M., \& Im, S. (2015). Strategic planning as a complex and enabling managerial tool. Strategic Management Journal, 38(8), 1741-1752. DOI: https://doi.org/10.1002/smj.2420

Arroyo, M. R., Fuentes, M. del M., \& Jiménez, J. M. R. (2016). Um estudo internacional sobre os factores que explicam a expectativa de alto crescimento em novos empreendimentos: uma perspectiva de gênero. Revista Brasileira de Gestão de Negócios, 18(60), 171-190.

Retrieved from: http://www.scielo.br/pdf/rbgn/v18n60/1806-4892-rbgn-18-60-00171.pdf

Audretsch, D. B. (2012). Determinants of high-growth entrepreneurship. In OECD/DBA International Workshop on "High-growth firms: local policies and local determinants". Copenhagen, Denmark, 28 March 2012 (pp. 1-37). Paris, France: OECD / Copenhagen, Denmark: Danish Business Authority. Retrieved from: https://www.oecd.org/cfe/leed/Audretsch determinants\%20of\%20high-growth\%20firms.pdf

Bager, T., \& Schøtt, T. (2004). Growth expectations by entrepreneurs in nascent firms, baby businesses and mature firms: Analysis of the Global Entrepreneurship Monitor surveys in Denmark 2000-2003. In GEM Research Conference: "Entrepreneurship, Government Policies and Economic Growth". Berlin, Germany, April 2004 (pp. 1-12). London, UK: Global Entrepreneurship Research Association. Retrieved from: http://citeseerx.ist.psu.edu/viewdoc/download;jsessionid=16A26586FB673F57FFEDBB8DCD557AD7?doi= 10.1.1.455.4936\&rep=rep1\&type $=$ pdf

Bamberger, P. A., Biron, M., \& Meshoulam, I. (2014). Human resource strategy: Formulation, implementation, and impact (Second Edition). New York, NY: Routledge.

Barbero, J. L., Casillas, J. C., \& Feldman, H. D. (2011). Managerial capabilities and paths to growth as determinants of high-growth small and medium-sized enterprises. International Small Business Journal, 29(6), 671-694. DOI: https://doi.org/10.1177/0266242610378287

Barney, J. B. (1991). Firm resources and sustained competitive advantage. Journal of Management, 17(1), 99-120. DOI: https://doi.org/10.1177/014920639101700108

Barringer, B. R., \& Greening, D. W. (1998). Small business growth through geographic expansion: A comparative case study. Journal of Business Venturing, 13(6), 467-492. DOI: https://doi.org/10.1016/S0883-9026(97)00038-4

Barringer, B. R., Jones, F. F., \& Neubaum, D. O. (2005). A quantitative content analysis of the characteristics of rapid-growth firms and their founders. Journal of Business Venturing, 20(5), 663-687. DOI: https://doi.org/10.1016/i.jbusvent.2004.03.004

Bauer, F., Dao, M. A., Matzler, K., \& Tarba, S. Y. (2017). How industry lifecycle sets boundary conditions for M\&A integration. Long Range Planning, 50(4), 501-517. DOI: https://doi.org/10.1016/j.lrp.2016.09.002 
Baum, J. R., \& Locke, E. A. (2004). The relationship of entrepreneurial traits, skill, and motivation to subsequent venture growth. Journal of Applied Psychology, 89(4), 587-598. DOI: https://doi.org/10.1037/0021-9010.89.4.587

Baum, J. R., Locke, E. A., \& Kirkpatrick, S. A. (1998). A longitudinal study of the relation of vision and vision communication to venture growth in entrepreneurial firms. Journal of Applied Psychology, 83(1), 43-54. DOI: https://doi.org/10.1037/0021-9010.83.1.43

Becchetti, L., \& Trovato, G. (2002). The determinants of growth for small and medium sized firms. The role of external finance. Small Business Economics, 19(4), 291-306. DOI: https://doi.org/10.1023/A:1019678429111

Belenzon, S., Shamshur, A., \& Zarutskie, R. (2019). CEO's age and the performance of closely held firms. Strategic Management Journal 40(6), 917-944. DOI: https://doi.org/10.1002/smj.3003

Bibu, N. A., \& Sala, D. C. (2014). Aspects of fast growth in Romanian companies. The case of a successful company in Timis County. Procedia - Social and Behavioral Sciences, 124, 263-271. DOI: https://doi.org/10.1016/j.sbspro.2014.02.485

Binks, M. R., \& Ennew, C. T. (1996). Growing firms and the credit constraint. Small Business Economics, 8(1), 17-25. DOI: https://doi.org/10.1007/BF00391972

Bottazzi, G., \& Secchi, A. (2006). Explaining the distribution of firm growth rates. RAND Journal of Economics, $37(2), 235-256$.

Received from: http://dimetic.dime-eu.org/dimetic files/Lect-7-to-Secchi-Bottazzi-Secchi.pdf

Boubakri, N., El Ghoul, S., \& Saffar, W. (2015). Firm growth and political institutions. Journal of Multinational Financial Management, 31, 104-125. D0I: https://doi.org/10.1016/i.mulfin.2015.05.003

Brenner, T., \& Schimke, A. (2015). Growth development paths of firms-A study of smaller businesses. Journal of Small Business Management, 53(2), 539-557. DOI: https://doi.org/10.1111/jsbm.12081

Burger, A., Damijan, J. P., Kostevc, C., \& Rojec, M. (2017). Determinants of firm performance and growth during economic recession: The case of Central and Eastern European countries. Economic Systems, 41(4), 569-590. DOI: https://doi.org/10.1016/j.ecosys.2017.05.003

Cagetti, M., \& Nardi, M. de (2006). Entrepreneurship, frictions, and wealth. Journal of Political Economy, 114(5), 835-870. DOI: https://doi.org/10.1086/508032

Canarella, G., \& Miller, S. M. (2018). The determinants of growth in the U.S. information and communication technology (ICT) industry: A firm-level analysis. Economic Modelling, 70, 259-271. DOI: https://doi.org/10.1016/j.econmod.2017.11.011

Carpenter, R. E., \& Petersen, B. C. (2002). Is the growth of small firms constrained by internal finance? Review of Economics and Statistics, 84(2), 298-309. DOI: https://doi.org/10.1162/003465302317411541

Cassar, G. (2006). Entrepreneur opportunity costs and intended venture growth. Journal of Business Venturing, 21(5), 610-632. DOI: https://doi.org/10.1016/i.jbusvent.2005.02.011

Cassia, L., Colombelli, A., \& Paleari, S. (2009). Firms' growth: Does the innovation system matter? Structural Change and Economic Dynamics, 20(3), 211-220. DOI: https://doi.org/10.1016/j.strueco.2009.01.001

Casson, M. (2005). Entrepreneurship and the theory of the firm. Journal of Economic Behavior \& Organization, 58(2), 327-348. DOI: https://doi.org/10.1016/j.jebo.2004.05.007

Chandler, A. D. (1980). The growth of the transnational industrial firm in the United States and the United Kingdom: A comparative analysis published by. The Economic History Review, 33(3), 396-410. DOI: https://doi.org/10.2307/2595196

Chandler, G. N., \& Hanks, S. H. (1994). Founder competence, the environment, and venture performance. Entrepreneurship: Theory \& Practice, 18(3), 77-89. DOI: https://doi.org/10.1177/104225879401800306

Cliff, J. E. (1998). Does one size fit all? Exploring the relationship between attitudes towards growth, gender, and business size. Journal of Business Venturing, 13(6), 523-542. DOI: https://doi.org/10.1016/S0883-9026(97)00071-2

Coad, A. (2007). Firm growth: A survey. CES Working Papers 2007.24. Paris, France: Centre d'Economie de la Sorbonne. Retrieved from: https://halshs.archives-ouvertes.fr/halshs-00155762/document

Coad, A., \& Tamvada, J. P. (2012). Firm growth and barriers to growth among small firms in India. Small Business Economics, 39(2), 383-400. DOI: https://doi.org/10.1007/s11187-011-9318-7

Coad, A., Daunfeldt, S.-O., \& Halvarsson, D. (2018). Bursting into life: Firm growth and growth persistence by age. Small Business Economics, 50(1), 55-75. DOI: http://dx.doi.org/10.2139/ssrn.2616759

Coad, A., Segarra, A., \& Teruel, M. (2013). Like milk or wine: Does firm performance improve with age? Structural Change and Economic Dynamics, 24(1), 173-189. DOI: https://doi.org/10.1016/j.strueco.2012.07.002 
Coad, A., Segarra, A., Teruel, M. (2016). Innovation and firm growth: Does firm age play a role? Research Policy, 45(2), 387-400. DOI: https://doi.org/10.1016/j.respol.2015.10.015

Colombo, M. G., \& Grilli, L. (2005). Founders' human capital and the growth of new technology-based firms: A competence-based view. Research Policy, 34(6), 795-816. DOI: https://doi.org/10.1016/i.respol.2005.03.010

Cooley, T. F., \& Quadrini, V. (2001). Financial markets and firm dynamics. The American Economic Review, 91(5), 1286-1310. DOI: https://doi.org/10.1257/aer.91.5.1286

Cooper, A. C., Gimeno-Gascón, F. J., \& Woo, C. Y. (1994). Initial human and financial capital as predictors of new venture performance. Journal of Business Venturing, 9(5), 371-395. DOI: https://doi.org/10.1016/0883-9026(94)90013-2

Cuervo-Cazurra, A., de Holan, P. M., \& Sanz, L. (2014). Location advantage: Emergent and guided co-evolutions. Journal of Business Research, 67(4), 508-515. D0I: https://doi.org/10.1016/i.jbusres.2013.11.007

Davidsson, P. (1989). Continued entrepreneurship and small firm growth. Stockholm, Sweden: Stockholm School of Economics, Economic Research Institut.

Davidsson, P. (1991). Continued entrepreneurship: Ability, need, and opportunity as determinants of small firm growth. Journal of Business Venturing, 6(6), 405-429. DOI: https://doi.org/10.1016/0883-9026(91)90028-C

Davidsson, P., Achtenhagen, L., \& Naldi, L. (2005). Research on small firm growth: A review. In 35th EISB Conference: Sustaining the entrepreneurial spirit over time: Implications for young companies, family businesses, and established companies. Barcelona, Spain (pp. 1-27).

Retrieved from: https://core.ac.uk/download/pdf/10874106.pdf

Davidsson, P., Achtenhagen, L., \& Naldi, L. (2010). Small firm growth. Foundations and Trends in Entrepreneurship, 6(2), 69-166. DOI: http://dx.doi.org/10.1561/0300000029

Davidsson, P., Kirchhoff, B., Hatemi-J, A., \& Gustavsson, H. (2002). Empirical analysis of business growth factors using Swedish data. Journal of Small Business Management, 40(4), 332-349.

DOI: https://doi.org/10.1111/1540-627X.00061

Delmar, F. (1996). Entrepreneurial behavior and business performance. Stockholm, Sweden: Stockholm School of Economics.

Delmar, F., \& Wiklund, J. (2008). The effect of small business managers' growth motivation on firm growth: A longitudinal study. Entrepreneurship Theory and Practice, 32(3), 437-457. DOI: https://doi.org/10.1111/i.1540-6520.2008.00235.x

Demir, R., Wennberg, K., \& McKelvie, A. (2017). The strategic management of high-growth firms: A review and theoretical conceptualization. Long Range Planning, 50(4), 431-456. DOI: https://doi.org/10.1016/j.lrp.2016.09.004

Distante, R., Petrella, I., \& Santoro, E. (2018). Gibrat's law and quantile regressions: An application to firm growth. Economics Letters, 164, 5-9. DOI: https://doi.org/10.1016/i.econlet.2017.12.028

Djankov, S., La Porta, R., López-de-Silanes, F., \& Shleifer, A. (2002). The regulation of entry. Quarterly Journal of Economics, 117(1), 1-37. DOI: https://doi.org/10.1162/003355302753399436

Dobbs, M., \& Hamilton, R.T. (2007). Small business growth: Recent evidence and new directions. International Journal of Entrepreneurial Behavior \& Research, 13(5), 296-322. DOI: https://doi.org/10.1108/13552550710780885

Drucker, P.F. (1999). Management (Revised Edition). Toronto, ON: HarperCollins Canada.

Du, J., \& Temouri, Y. (2015). High-growth firms and productivity: Evidence from the United Kingdom. Small Business Economics, 44(1), 123-143. DOI: https://doi.org/10.1007/s11187-014-9584-2

Duchesneau, D. A., \& Gartner, W. B. (1990). A profile of new venture success and failure in an emerging industry. Journal of Business Venturing, 5(5), 297-312. DOI: https://doi.org/10.1016/0883-9026(90)90007-G

Duschl, M., Schimke, A., Brenner, T., \& Luxen, D. (2011). Firm growth and the spatial impact of geolocated external factors - empirical evidence for German manufacturing firm. Working Paper Series in Economics, No. 36. Karlsruhe, Germany: Karlsruhe Institute of Technology (KIT). DOI: http://dx.doi.org/10.5445/IR/1000024923

Dutta, D. K., \& Thornhill, S. (2008). The evolution of growth intentions: Toward a cognition-based model. Journal of Business Venturing, 23(3), 307-332. DOI: https://doi.org/10.1016/j.jbusvent.2007.02.003

Edelman, L. F., Brush, C. G., Manolova, T. S., \& Greene, P. G. (2010). Start-up motivations and growth intentions of minority nascent entrepreneurs. Journal of Small Business Management, 48(2), 174-196. DOI: http://dx.doi.org/10.1111/j.1540-627X.2010.00291.x

Evans, D. S. (1987). The relationship between firm growth, size, and age: Estimates for 100 manufacturing industries. The Journal of Industrial Economics, 35(4), 567-581. DOI: https://doi.org/10.2307/2098588 
Fadahunsi, A. (2012). The growth of small businesses: Towards a research agenda. American Journal of Economics and Business Administration, 4(1), 105-115. DOI: https://doi.org/10.3844/ajebasp.2012.105.115

Fazzari, S. M., Hubbard, R. G., Petersen, B. C., Blinder, A. S., \& Poterba, J. M. (1988). Financing constraints and corporate investment. Brookings Papers on Economic Activity, 1,141-206. DOI: https://doi.org/10.2307/2534426

Florin, J., Lubatkin, M., \& Schulze, W. (2003). A social capital model of high growth ventures. Academy of Management Journal, 46(3), 364-374.

Folta, T. B., Cooper, A. C., \& Baik, Y. S. (2006). Geographic cluster size and firm performance. Journal of Business Venturing, 21(2), 217-242. DOI: https://doi.org/10.1016/j.jbusvent.2005.04.005

Gibrat, R. (1931). Les inégalités économiques. Paris, France: Recueil Sirey.

Gilbert, B. A., McDougall, P. P., \& Audretsch, D. B. (2006). New venture growth: A review and extension. Journal of Management, 32(6), 926-950. DOI: https://doi.org/10.1177/0149206306293860

Gimeno, J., Folta, T. B., Cooper, A. C., \& Woo, C. Y. (1997). Survival of the fittest? Entrepreneurial human capital and the persistence of underperforming firms. Administrative Science Quarterly, 42(4), 750-83. DOI: https://doi.org/10.2307/2393656

Glancey, K. (1998). Determinants of growth and profitability in small entrepreneurial firms. International Journal of Entrepreneurial Behaviour \& Research, 4(1), 18-27. DOI: https://doi.org/10.1108/13552559810203948

Gopinath, R. C. (2012). Understanding the determinants of firm growth in young REITS. In 19th Annual European Real Estate Society Conference. Edinburgh, Scotland, 13-16 June 2012. DOI: https://doi.org/10.15396/eres2012_205

Greiner, L. E. (1972). Evolution and revolution as organizations grow. Harvard Business Review, 37-46.

Guariglia, A., Liu, X., \& Song, L. (2011). Internal finance and growth: Microeconometric evidence on Chinese firms. Journal of Development Economics, 96(1), 79-94. DOI: https://doi.org/10.1016/j.jdeveco.2010.07.003

Gundry, L. K., \& Welsch, H. P. (2001). The ambitious entrepreneur: High growth strategies of women-owned enterprises. Journal of Business Venturing, 16(5), 453-470. DOI: https://doi.org/10.1016/S0883-9026(99)00059-2

Gupta, P. D., Guha, S., \& Krishnaswami, S. S. (2013). Firm growth and its determinants. Journal of Innovation and Entrepreneurship, 2(1), 2-15. DOI: https://doi.org/10.1186/2192-5372-2-15

Hall, B. H. (1987). The relationship between firm size and firm growth in the US manufacturing sector. The Journal of Industrial Economics, 35(4), 583-606. DOI: https://doi.org/10.2307/2098589

Haltiwanger, J., Jarmin, R. S., \& Miranda, J. (2013). Who creates jobs? Small versus large versus young. The Review of Economics and Statistics, 95(2), 347-361.

Retrieved from: https://www.mitpressjournals.org/doi/pdf/10.1162/REST_a 00288

Hampel-Milagrosa, A., Loewe, M., \& Reeg, C. (2015). The entrepreneur makes a difference: Evidence on MSE upgrading factors from Egypt, India, and the Philippines. World Development, 66, 118-130.

DOI: https://doi.org/10.1016/j.worlddev.2014.08.005

Harabi, N. (2007). Determinants of firm growth: An empirical analysis from Morocco. Munich Personal RePEc Archive Paper No. 4394. Munich, Germany: University Library of Munich, MPRA Paper. Retrieved from: https://core.ac.uk/download/pdf/7304396.pdf

Harhoff, D., Stahl, K., \& Woywode, M. (1998). Legal form, growth and exit of West German firms - empirical results for manufacturing, construction, trade and service industries. Journal of Industrial Economics, 46(4), 453-488. DOI: https://doi.org/10.1111/1467-6451.00083

Hassan, R. S., \& Hart, M. (2016). The determinants of small firm growth: An empirical study on Egypt. The Business and Management Review, 7(2), 41-52.

Retrieved from: https://cberuk.com/cdn/conference proceedings/conference 84786.pdf

Hermelo, F. D., \& Vassolo, R. (2007). The determinants of firm's growth: An empirical examination. Revista Abante, 10(1), 3-20.

Hoogstra, G. J., \& van Dijk, J. (2004). Explaining firm employment growth: Does location matter? Small Business Economics, 22, 179-192. DOI: https://doi.org/10.1023/B:SBEJ.0000022218.66156.ac

Hove, P., \& Tarisai, C. (2013). Internal factors affecting the successful growth and survival of small and micro agri-business firms in Alice Communal Area. Journal of Economics, 4(1), 57-67. DOI: https://doi.org/10.1080/09765239.2013.11884965

Jarillo, J. C. (1989). Entrepreneurship and growth: The strategic use of external resources. Journal of Business Venturing, 4(2), 133-147. DOI: https://doi.org/10.1016/0883-9026(89)90027-X 
Jovanovic, B., \& MacDonald, G. M. (1994). The life cycle of a competitive industry. Journal of Political Economy, 102(2), 322-347. Retrieved from: http://apps.olin.wustl.edu/workingpapers/pdf/2004-03-057.pdf

Kangasharju, A. (2000). Growth of the smallest: Determinants of small firm growth during strong macroeconomic fluctuations. International Small Business Journal, 19(1), 28-43. DOI: https://doi.org/10.1177/0266242600191002

Karadeniz, E., \& Özçam, A. (2010). The determinants of the growth expectations of the early-stage entrepreneurs (TEA) using the ordinal logistic model (OLM): The case of Turkey. Economic and Business Review, 12(1), 61-84. Retrieved from: https://ojs.ebrjournal.net/ojs/index.php/ebr/article/view/41

Khan, K. S. (2011). Determinants of firm growth: An empirical examination of SMEs in Gujranwala, Gujarat and Sialkot districts. Interdisciplinary Journal of Contemporary Research in Business, 3(1), 1389-1409.

Klag, M., \& Langley, A. (2014). Critical junctures in strategic planning: Understanding failure to enable success. Organizational Dynamics, 43(4), 274-283. DOI: https://doi.org/10.1016/j.orgdyn.2014.09.004

Klepper, S. (1996). Entry, exit, growth, and innovation over the product life cycle. American Economic Review, 86(3), 562-583.

Knight, F. (1921). Risk, uncertainty and profit. Boston, MA: Houghton Mifflin.

Kolvereid, L. (1992). Growth aspirations among Norwegian entrepreneurs. Journal of Business Venturing, 7(3), 209-222. DOI: https://doi.org/10.1016/0883-9026(92)90027-0

Kumar, R. (2016). Human capital management as a source of competitive advantage in a developing economy. International Journal for Administration in Management, Commerce and Economics, 6, 122-129.

Kunt-Demirgüç, A., \& Maksimovic, V. (1998). Law, finance, and firm growth. Journal of Finance, 53(6), $2107-2137$. DOI: https://doi.org/10.1111/0022-1082.00084

Lee, C.-C., Wang, C.-W., \& Ho, S.-J. (2019). Financial inclusion, financial innovation, and firms' sales growth. International Review of Economics and Finance, 66, 189-205. DOI: https://doi.org/10.1016/j.iref.2019.11.021

Lee, C.-Y. (2018). Geographical clustering and firm growth: Differential growth performance among clustered firms. Research Policy, 47, 1173-1184. DOI: https://doi.org/10.1016/j.respol.2018.04.002

Lee, K., \& Temesgen T. (2005). Determinants of firms growth in developing countries: An extension of the resource-based theory of firm growth. In WIDER Jubilee Conference on The Future of Development Economics. Helsinki, Finland, June 2005.

Liedholm, C. (2002). Small firm dynamics: Evidence from Africa and Latin America. Small Business Economics, 18, 227-242. DOI: https://doi.org/10.1023/A:1015147826035

Lucas, R. E. (1978). On the size distribution of business firms. The Bell Journal of Economics, 9(2), 508-523. DOI: https://doi.org/10.2307/3003596

Mankiw, G.N. (1995). The growth of nations. Brookings Papers on Economic Activity, 1, 275-326.

Mateev, M., \& Anastasov, Y. (2010). Determinants of small and medium sized fast-growing enterprises in Central and Eastern Europe: A panel data analysis. Financial Theory and Practice, 34(3), 269-295.

Mazzarol, T., Reboud, S., \& Soutar, G. N. (2009). Strategic planning in growth oriented small firms. International Journal of Entrepreneurial Behavior \& Research, 15(4), 320-345. DOI: https://doi.org/10.1108/13552550910967912

McKelvie, A., \& Wiklund, J. (2010). Advancing firm growth research: A focus on growth mode instead of growth rate. Entrepreneurship: Theory and Practice, 34(2), 261-288. DOI: https://doi.org/10.1111/i.1540-6520.2010.00375.x

McPherson, M. A. (1996). Growth of micro and small enterprises in southern Africa. Journal of Development Economics, 48(2), 253-277. DOI: https://doi.org/10.1016/0304-3878(95)00027-5

Meijaard, J., Brand, M. J., \& Mosselman, M. (2005). Organizational structure and performance in Dutch small firms. Small Business Economics, 25(1), 83-96. DOI: https://doi.org/10.1007/s11187-005-4259-7

Mintzberg, H. (1979). The structuring of organizations. Englewood Cliffs, NJ: Prentice Hall.

Morone, P., \& Testa, G. (2008). Firms growth, size and innovation an investigation into the Italian manufacturing sector. Economics of Innovation and New Technology, 17(4), 311-329. DOI: https://doi.org/10.1080/10438590701231160

Mount, J., Zinger, J. T., \& Forsyth, G. R. (1993). Organizing for development in the small business. Long Range Planning, 26(5), 111-120. DOI: https://doi.org/10.1016/0024-6301(93)90083-R

Nelson, R. R., \& Winter, S. G. (1982). An evolutionary theory of economic change. Cambridge, MA: Harvard University Press.

Nichter, S., \& Goldmark, L. (2009). Small firm growth in developing countries. World Development, 37(9), 1453-1464. DOI: https://doi.org/10.1016/j.worlddev.2009.01.013 
O'Gorman, C. (2001). The sustainability of growth in small - and medium-sized. International Journal of Entrepreneurial Behaviour \& Research, 7(2), 60-75. DOI: https://doi.org/10.1108/13552550110396095

Oliveira, B., \& Fortunato, A. (2006). Firm growth and liquidity constraints: A dynamic analysis. Small Business Economics, 27, 139-156. DOI: https://doi.org/10.1007/s11187-006-0006-y

Oliveira, B., \& Fortunato, A. (2003). Testing Gibrat's law: Empirical evidence from a panel of Portuguese manufacturing firms. Estudos do GEMF, 7, 1-33. Retrieved from: https://core.ac.uk/download/pdf/6671243.pdf

Olomi, D. R. (2001). Evolution of entrepreneurial motivation: The transition from economic necessity to entrepreneurship. Business Management Review, 7(2), 107-136. Retrieved from: https://journals.co.za/doi/pdf/10.10520/AJA08562253 74

Ortiz-de-Urbina-Criado, M., Guerras-Martín, L. A., \& Montoro-Sánchez, A. (2014). The choice of growth method: Strategies and resources. Academia Revista Latinoamericana de Administración, 27(1), 30-45. DOI: https://doi.org/10.1108/ARLA-07-2013-0094

Ostgaard, T. A., \& Birley, S. (1996). New venture growth and personal networks. Journal of Business Research, 36(1), 37-50. DOI: https://doi.org/10.1016/0148-2963(95)00161-1

Pålsson, A.-M. (1996). Does the degree of relative risk aversion vary with household characteristics? Journal of Economic Psychology, 17, 771-787. DOI: https://doi.org/10.1016/S0167-4870(96)00039-6

Parker, S. C. (2009). The economics of entrepreneurship. Cambridge, UK: Cambridge University Press. DOI: https://doi.org/10.1017/9781316756706

Pe'er, A., Vertinsky, I., \& Keil, T. (2016). Growth and survival: The moderating effects of local agglomeration and local market structure. Strategic Management Journal, 37(3), 541-564. DOI: https://doi.org/10.1002/smj.2331

Penrose, E. (1959). The theory of the growth of the firm (Fourth Edition). Oxford, UK: Oxford University.

Picken, J. C. (2017). From founder to CEO: An entrepreneur's roadmap. Business Horizons, 60(1), 7-14. DOI: https://doi.org/10.1016/i.bushor.2016.09.004

Pissarides, F. (1999). Is lack of funds the main obstacle to growth? EBRD's experience with small -and mediumsized businesses in central and eastern Europe. Journal of Business Venturing, 14, 519-539.

Porter, M. E. (1985). Competitive advantage: Creating and sustaining superior performance. New York, NY: Free Press.

Porter, M. E. (1999). Campetição on competition-estratégias competitivas essenciais (Segunda Edição). Rio de Janeiro, Brazil: Campos.

Psenicny, V. (2009). A longitudinal comparison of the growth factors of slovenian fast-growing enterprises. Economic and Business Review, 11(4), 265-284. Retrieved from: http://www.doba.si/ftp/fakulteta/psenicny/Psenicny_Longitudinal\%20ComparisonL\%20230410F.pdf

Pyke, F., Becattini, G., \& Sengenberger, W. (1990). Industrial districts and inter-firm co-operation in Italy. Geneva, Switzerland: International Institute for Labour Studies.

Rafiki, A. (2019). Determinants of SME growth: An empirical study in Saudi Arabia. International Journal of Organizational Analysis, 28(1), 205-225. DOI: https://doi.org/10.1108/IJOA-02-2019-1665

Rahaman, M. M. (2011). Access to financing and firm growth. Journal of Banking and Finance, 35(3), 709-723. Retrieved from: https://papers.ssrn.com/sol3/papers.cfm?abstract id=1624006

Rajan, R. G., \& Zingales, L. (1998). Financial dependence and growth. The American Economic Review, 88(3), 559-586. Retrieved from: https://www.jstor.org/stable/116849?seq=1

Rauch, A., Frese, M., \& Utsch, A. (2005). Effects of human capital and long-term human resources development and utilization on employment growth of small-scale businesses: A causal analysis. Entrepreneurship: Theory and Practice, 29(6), 681-698. DOI: https://doi.org/10.1111/j.1540-6520.2005.00103.x

Reeg, C. (2013). Micro, small and medium enterprise upgrading in low- and middle-income countries: A literature review. DIE Discussion Paper 15/2013. Bonn, Germany: Deutsches Institut für Entwicklungspolitik. Retrieved from: https://www.die-gdi.de/uploads/media/DP 15.2013.pdf

Romer, P. M. (1986). Increasing returns and long-run growth. Journal of Political Economy, 94(5), 1002-1037. Retrieved from: https://www.jstor.org/stable/1833190?seq=1

Romer, P. M. (1990). Endogenous technological change. Journal of Political Economy, 98(5, Part 2), S71-S102. Retrieved from: https://www.jstor.org/stable/2937632?seq=1

Sapienza, H. J., Autio, E., George, G., \& Zahra, S. A. (2006). A capabilities perspective on the effects of early internationalization on firm survival and growth. Academy of Management Review, 31(4), 914-933. DOI: https://doi.org/10.2307/20159258 
Schein, E. H. (2004). Organizational culture and leadership (Third Edition). San Francisco, CA: Jossey-Bass.

Schumpeter, J. A. (1934). The theory of economic development: an inquiry into profits, capital credit, interest, and the business cycle. Cambridge, MA: Harvard University Press.

Scott, M., \& Bruce, R. (1987). Five stages of growth business in small business. London Business School Journal, $20(3), 45-52$.

Segarra, A., \& Teruel, M. (2009). Small firms, growth and financial constraints. SSRN Electronic Journal, 1-32. DOI: https://doi.org/10.2139/ssrn.1825064

Sexton, D. L., \& Bowman, N. (1985). The entrepreneur: A capable executive and more. Journal of Business Venturing, 1(1), 129-140. DOI: https://doi.org/10.1016/0883-9026(85)90012-6

Shuman, C., Shaw, J. J., \& Sussman, G. (1985). Strategic planning in smaller rapid growth companies. Long Range Planning, 18(6), 48-53. DOI: https://doi.org/10.1016/0024-6301(85)90063-9

Siegel, R., Siegel, E., \& Macmillan, I.C. (1993). Characteristics distinguishing high-growth ventures. Journal of Business Venturing, 8(2), 169-180. DOI: https://doi.org/10.1016/0883-9026(93)90018-Z

Silva, F., \& Carreira, C. (2011). Do financial constraints threat the innovation process? Evidence from Portuguese firms. Estudos do GEMF, 10, 1-50.

Retrieved from: http://www4.fe.uc.pt/gemf/workingpapers/pdf/2011/gemf 2011-10 v2.pdf

Simbaña-Taipe, L. E., Rodríguez-Gulías, M. J., \& Rodeiro-Pazos, D. (2018). 0 non cumprimento da lei de Gibrat en economías en desenvolvemento: o caso de Ecuador no período 2000-2013. Revista Galega De Economía, 27(2), 85-98. Retrieved from: https://revistas.usc.gal/index.php/rge/article/view/5660

Singh, A., \& Whittington, G. (1975). The size and growth of firms. The Review of Economic Studies, 42(1), 15-26. DOI: https://doi.org/10.2307/2296816

Sirmon, D. G., Hitt, M. A., \& Ireland, R. D. (2007). Managing firm resources in dynamic environments to create value: Looking inside the black box. Academy of Management Review, 32(1), 273-292. DOI: https://doi.org/10.5465/amr.2007.23466005

Smallbone, D., Leig, R., \& North, D. (1995). The characteristics and strategies of high growth SMEs. International Journal of Entrepreneurial Behaviour \& Research, 1(3), 44-62. DOI: https://doi.org/10.1108/13552559510100657

Stam, W., Arzlanian, S., \& Elfring, T. (2014). Social capital of entrepreneurs and small firm performance: A metaanalysis of contextual and methodological moderators. Journal of Business Venturing, 29(1), 152-173. DOI: https://doi.org/10.1016/i.jbusvent.2013.01.002

Storey, D. J. (1994). Understanding the small business sector. London, UK: Routledge.

Storey, D. J. (2011). Optimism and chance: The elephants in the entrepreneurship room. International Small Business Journal, 29(4), 303-321. DOI: https://doi.org/10.1177/0266242611403871

Street, C. T., \& Cameron, A.-F. (2007). External relationships and the small business: A review of small business alliance and network research. Journal of Small Business Management, 45(2), 239-266. DOI: https://doi.org/10.1111/i.1540-627X.2007.00211.x

Sutton, J. (1997). Gibrat's legacy. Journal of Economic Literature, 35(1), 40-59. Retrieved from: http://darp.lse.ac.uk/PapersDB/Sutton (JEL97).pdf

Tarfasa, S., Ferede, T., Kebede, S., \& Behailu, D. (2016). Determinants of growth of micro and small enterprises (MSEs): Empirical evidence from Ethiopia. Swiss Programme for Research on Global Issues for Development R4D Working Paper 2016/3. Retrieved from: https://www.wti.org/media/filer public/d9/24/d924ca536f68-472e-a26b-45190f1418fb/wp_2016 03 growth determinants mses ethiopia.pdf

Todd, A., \& Taylor, B. (1993). The baby sharks: Strategies of Britain's super growth companies. Long Range Planning, 26(2), 69-77. DOI: https://doi.org/10.1016/0024-6301(93)90137-5

Ullah, B. (2019). Financial constraints, corruption, and SME growth in transition economies. Quarterly Review of Economics and Finance, 75, 120-132. DOI: https://doi.org/10.1016/j.qref.2019.05.009

Variyam, J. N., \& Kraybill, D. S. (1992). Empirical evidence on determinants of firm growth. Economics Letters, 38(1), 31-36. DOI: https://doi.org/10.1016/0165-1765(92)90157-T

Watson, W., Stewart, W. H., \& BarNir, A. (2003). The effects of human capital, organizational demography, and interpersonal processes on venture partner perceptions of firm profit and growth. Journal of Business Venturing, 18(2), 145-164. DOI: https://doi.org/10.1016/S0883-9026(01)00082-9

Wennberg, K., Delmar, F., \& McKelvie, A. (2016). Variable risk preferences in new firm growth and survival. Journal of Business Venturing, 31(4), 408-427. DOI: https://doi.org/10.1016/i.jbusvent.2016.05.001

Whetten, D. A. (1987). Organizational growth and decline processes. Annual Review of Sociology, 13, 335-358. Retrieved from: https://www.jstor.org/stable/2083252?seq=1 
Wiklund, J. (1998). Small firm growth and performance entrepreneurship and beyond. (Doctoral thesis). Jönköping Universityy. Retrieved from: http://hj.diva-portal.org/smash/record.jsf?pid=diva2\%3A3910\&dswid=-2382

Wiklund, J., Patzelt, H., \& Shepherd, D. A. (2009). Building an integrative model of small business growth. Small Business Economics, 32(4), 351-374. DOI: https://doi.org/10.1007/s11187-007-9084-8

Wintrobe, R., \& Breton, A. (1986). Organizational structure and productivity. American Economic Review, 76(3), 530-538. Retrieved from: https://www.jstor.org/stable/1813370?seq=1

Wright, M., \& Stigliani, I. (2012). Entrepreneurship and growth. International Small Business Journal, 31(1), 3-22. DOI: https://doi.org/10.1177/0266242612467359

Yao, R., Sharpe, D. L., \& Wang, F. (2011). Decomposing the age effect on risk tolerance. Journal of Socio-Economics, 40, 879-887. Retrieved from: https://isiarticles.com/bundles/Article/pre/pdf/12483.pdf

Zhao, L., \& Aram, J. D. (1995). Networking and growth of young technology-intensive ventures in China. Journal of Business Venturing, 10(5), 349-370. DOI: https://doi.org/10.1016/0883-9026(95)00039-B

Zhou, H., \& Wit, G. de (2009). Determinants and dimensions of firm growth. SCALES EIM Research Reports (H200903). Zoetermeer, Netherlands: EIM. DOI: http://dx.doi.org/10.2139/ssrn.1443897 